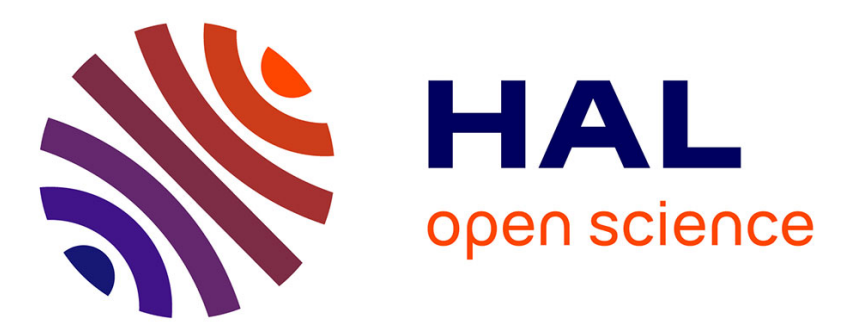

\title{
Contribution of tree-ring analysis to the study of droughts in northwestern France (XIX-XXth century)
}

O. Planchon, Vincent Dubreuil, Vincent Bernard, Sophie Blain

\section{To cite this version:}

O. Planchon, Vincent Dubreuil, Vincent Bernard, Sophie Blain. Contribution of tree-ring analysis to the study of droughts in northwestern France (XIX-XXth century). Climate of the Past Discussions, 2008, 4 (1), pp.249-270. hal-00330741

\section{HAL Id: hal-00330741 \\ https://hal.science/hal-00330741}

Submitted on 15 Oct 2008

HAL is a multi-disciplinary open access archive for the deposit and dissemination of scientific research documents, whether they are published or not. The documents may come from teaching and research institutions in France or abroad, or from public or private research centers.
L'archive ouverte pluridisciplinaire HAL, est destinée au dépôt et à la diffusion de documents scientifiques de niveau recherche, publiés ou non, émanant des établissements d'enseignement et de recherche français ou étrangers, des laboratoires publics ou privés. 


\section{Contribution of tree-ring analysis to the study of droughts in northwestern France (XIX-XXth century)}

\section{O. Planchon ${ }^{1}$, V. Dubreuil ${ }^{1}$, V. Bernard ${ }^{2}$, and S. Blain ${ }^{3}$}

${ }^{1}$ COSTEL LETG, UMR 6554 CNRS, Université Rennes-2, Place Recteur H. Le Moal, 35043 Rennes Cedex, France

${ }^{2}$ Civilisations Atlantiques et Archéosciences UMR 6566 CNRS, Université Rennes-1, 263 Avenue du général Leclerc, 35042 Rennes Cedex, France

${ }^{3}$ Luminescence Laboratory, Dept. Of Archaeology, University of Durham, South Road, Durham, DH1 3LE / CRPAA UMR5060 IRAMAT CNRS, Université Bordeaux-3, Maison de l'Archéologie 33607 Pessac Cedex, France

Received: 20 December 2007 - Accepted: 9 January 2008 - Published: 25 February 2008 Correspondence to: O. Planchon (olivier.planchon@Uhb.fr)

Published by Copernicus Publications on behalf of the European Geosciences Union.
Tree-ring analysis and droughts in northwestern France

O. Planchon et al.

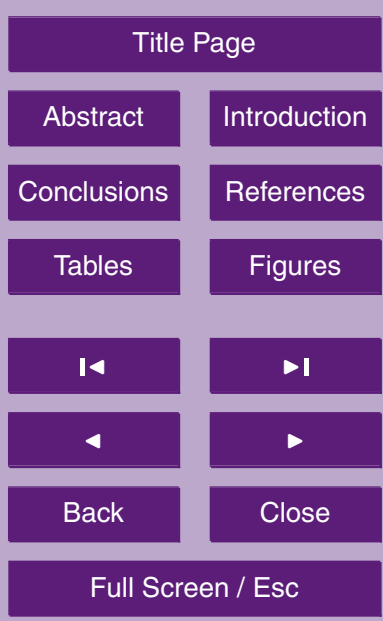

Printer-friendly Version

Interactive Discussion 


\section{Abstract}

A tree-ring analysis based on oak samples in the North-West of France showed the effects of droughts periods on the growth index, during the late XIXth and XXth century. Four types of droughts were identified using the results of the tree-ring analysis 5 and the available climate data. The "type 1" was subjected to a continuous and intense drought during all the vegetative period (spring and summer), the "type 2" was subjected to a summer drought succeeding no precipitation deficit in spring, the "type 3" was subjected to a remarkable winter drought and during the years of the "type 4", precipitation deficits were recorded for several but not successive months, over an heterogeneous spatial distribution. The long, intense and countinuous droughts clearly showed a spatial structuring effect on the growth index, especially when the two successive vegetative seasons (spring and summer) recorded strong precipitation deficits combined with shrivellings. These extreme cases involved the lowest growth index over most of the studied area, with some variations due to the altitude and exposure effects on the local-scale spatial distribution of the hydrological stress. The hydrological balance for the station of Rennes (Brittany) confirmed these results in accordance with the intensity and/or duration of drought periods: the most intense droughts of the "type 1" were especially pointed out. A climatic interpretation of growth index data and maps could so be possible over northwestern France with an application to the medieval times and perhaps to other periods, but the cause of the different drought patterns must be more precisely studied during the contemporary period (late XIXth century and all the XXth century).

\section{Introduction}

Several dendrochronological studies were carried out to estimate the most precisely the temperature variation during the last millenium in the northern hemisphere (Jones and Mann, 2004; Jones et al., 2001). Most of these studies proposed large-scale
4, 249-270, 2008

Tree-ring analysis and droughts in northwestern France

O. Planchon et al.

\section{Title Page}

Abstract

Introduction

Conclusions

References

Tables

Figures

14

$\Delta$

4

Back

$\checkmark$

Close

Full Screen / Esc

Printer-friendly Version

Interactive Discussion

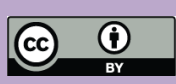


reconstructions of the temperature variability, pointing out time analysis rather than spatial analysis. Masson-Delmotte et al. (2005) analysed long-time (400 years) treering data series from timber woods and oaks of the area of Rennes (Brittany, western France), to show the precipitation seasonality and the drought frequency in a detailed 5 climatic reconstruction for all western Europe. The aim of this present paper is to propose a climatic interpretation of the regional-scale spatial distribution of the vegetation growth index over a less wide geographical area, but using several selected samples over all the studied area. Climate variability has an important economic weight on agriculture even in industrialized countries. In the temperate-oceanic areas of west10 ern Europe, the interannual climate variability, especially the variability of evaporation deficiency, may lead to social and economical impacts. The recent droughts in Europe have emphasised the vulnerability of European economies to shortages in water supply (Lloyd-Hughes, 2002). For example, in Brittany (western France), the main rural activities (maize and pasture lands) were strongly affected by the droughts of the 15 years 1989, 1990 and 2003. Major initiatives such as the ARIDE (Assessment of the Regional Impact of Droughts in Europe: see Stahl, 2001) and the WRINCLE (Water Resources: Influence of Climate change in Europe: see Kilsby, 2001) projects pointed out the importance of an improved understanding of drought in Europe. Since the middle of the $70 \mathrm{~s}$, an increase of the winter precipitation combined with a decrease of the summer precipitation was recorded in western France (Dubreuil et al., 1998) as well as in the British Isles (Mayes, 1996; Kiely, 1999). If these pluviometric features were associated with a climatic trend (as shown by most of global change scenarios: Stahl, 2001), their effects could cause real problems in the areas of intensive agriculture. Thus, a mapping of the space-time and regionalization of the extreme climate 25 features depending on their intensity (e.g. droughts in western Europe: Zaidman et al., 2001) should be precised using long data series. Tree rings are very useful and precise proxy data which allow to reconstruct the past climate variability. A dendrochronological analysis was carried out using data from oak trees in northwestern France, over the Armorican massif and a large part of the Paris basin. The data were first selected
4, 249-270, 2008

\section{Tree-ring analysis and droughts in northwestern France \\ O. Planchon et al.}
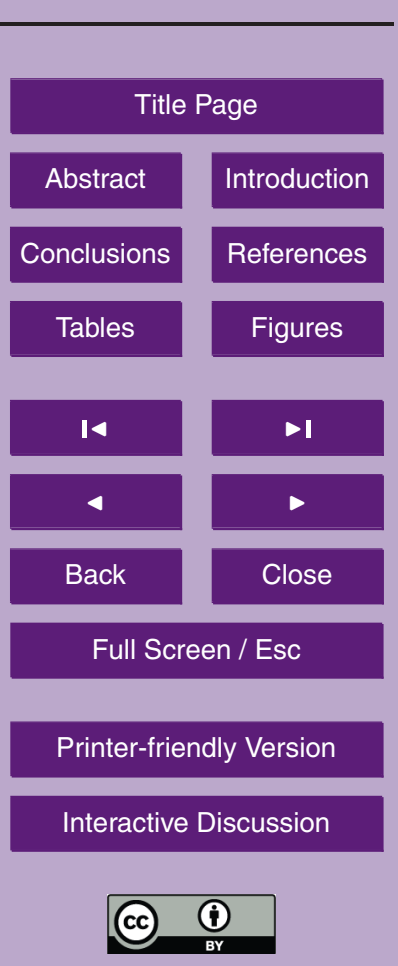
for the period 1880-1980, because the highest number of synchronous tree ring series was recorded during that period. The mapping of the results was carried out using a GIS.

The oceanic-temperate climate of northwestern France is usually subjected to the At5 lantic weather disturbances throughout the year. Their frequency and intensity present a seasonal variability which directly determines the precipitation regimes. The precipitation regime in north-western France is the result of the seasonal change in the circulation pattern in the mid- and high-latitudes over the North Atlantic Ocean and Europe. Autumn and winter are usually the rainiest seasons although the lie of the studied 10 area involves some regional and local differences in the precipitation amounts and in the seasonal distribution of precipitation. The relatively sheltered inland basins, valleys and flat plateaus experience a more equitably distribution of low amounts (locally less than $600 \mathrm{~mm}$ ) of precipitation throughout the year. The highest hills in NW France reach about 380-400 m in western Brittany and Normandy and precipitation is orographically enhanced on hillslopes presenting a westerly/southwesterly/southerly aspect (more than $1200 \mathrm{~mm}$ on the highest hilly areas). High annual precipitation amounts depending on heavy precipitation during the cold season are the distinctive feature of western Brittany and western Normandy (Fig. 1a), due to the exposure of these hilly areas to the prevailing Atlantic disturbance tracks. During early winter (December and January), the strong westerlies induce heavy precipitation and explain the rainiest period between November and January. The sheltered inland basins, valleys and low flat plateaus of eastern Brittany, the lower Loire valley area and the Paris basin experience a more equitably distribution of precipitation throughout the year. Precipitation is orographically enhanced on hillslopes presenting a westerly/southwesterly/southerly 25 aspect. The highest hills have heights of about $400 \mathrm{~m}$ in western Normandy and in western Brittany. At small scales, topographical effects locally influence effects of the circulation type on precipitation.

In summer the westerly circulation is relatively weak and the weather disturbances tracks are high in latitude. So relatively low rainfall amounts are recorded on the Euro-

\section{Tree-ring analysis and droughts in northwestern France \\ O. Planchon et al.}
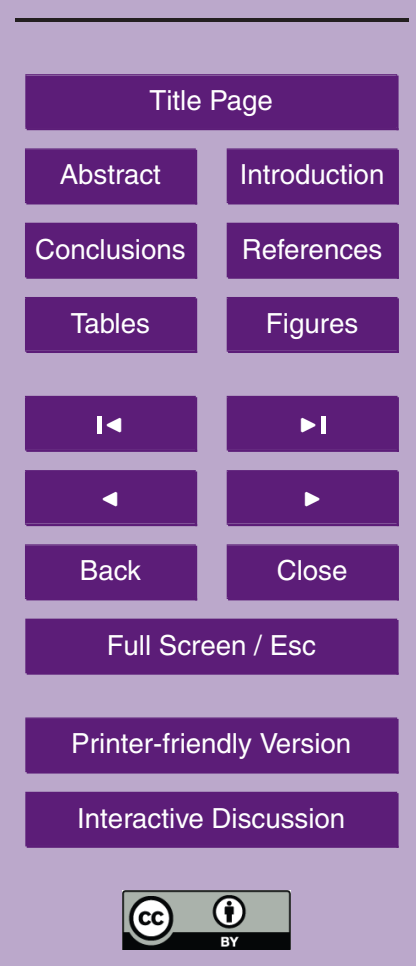
pean Atlantic fringe, especially in the southern part of the area. Consequently, summer is the less rainy season in most of northwestern France ranged between 14\% (west and south coast of Brittany) and about $25 \%$ (central and northern Paris basin) of the annual precipitation. Although precipitation deficits can occur throughout the year, the 5 warm season is especially subjected to drought periods in western France (Dubreuil, 1994 and 1997). Aridity index were developed taking precipitation and temperature into account. The spatial distribution of the aridity index of Emberger (1955) in northwestern France (period 1961-1990; Fig. 1b) is according to the spatial distribution of the annual precipitation, with the highest (=wettest conditions) index in western Brittany 10 and Normandy and the lowest (=driest conditions) index in the Loire valley. The driest conditions recorded in the Loire valley are strengthened by the relatively high summer maximum temperature $\left(\geq 25^{\circ} \mathrm{C}\right.$ in July).

\section{Methods and data}

\subsection{Dendroclimatology}

15 The dendrochronology is the analysis of the annual growth rings of trees, leading to the calculation of significant indices of climate and general chronology of the past. The width of a tree ring was determined by the temperature and/or the moisture that prevailed during the year of its formation. Since stress from temperature and/or moisture variations reduces the width of the seasonal growth of a tree ring, dendrochronology has important application in the study of long-term climatic variations (http://amsglossary.allenpress.com/glossary/browse). A statistical regression is used to show the connection between the climate instrumental data and the proxy data variability for the studied period. Dendrochronology allows to identify extreme climate events and their small-scale impacts, and also allows to propose a year-by-year precise dating. The synchronization of the tree ring series was based on the identification of characteristic years, which showed the same growth variations for at least $75 \%$ of
4, 249-270, 2008

Tree-ring analysis and droughts in northwestern France

O. Planchon et al.

\section{Title Page}

Abstract

Introduction

Conclusions

References

Tables

Figures

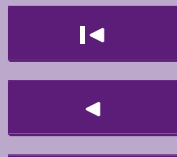

$\rightarrow 1$

Back

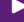

Close

Full Screen / Esc

Printer-friendly Version

Interactive Discussion

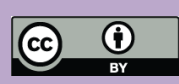


the selected trees (Lambert, 1998). The measure of tree-ring width is a significant indicator of the climatic effect on the tree growth, therefore the variation in tree-ring growth shows the climate variability too. The dendroclimatological data were standardized, in order to exclude the variation in growth due to the tree age and to decrease the anthro5 pogenic effect. The tree-ring data serie expressed in growth index allows to show the climatic effect more clearly. The climatic interpretation was only based on the negative characteristic years (showing a growth drop of the studied oaks). The comparison between the results of the dendroclimatological analysis and the available climate data for the period 1880-1980 allowed to identify the prevailing climatic features which caused 10 the growth drop of the oaks. The identification of the characteristic years was based on the intercomparison between average dendrochronological data of each of selected present-day forests.

\subsection{Tree-ring and climate data}

The data were recorded from oak trees over the Armorican massif and a large part of the Paris basin (Fig. 2a). The data recorded from alive trees samples were taken from the Dendron II database (Lambert), from the Tree-Ring Database available online at www. ncdc.noaa.gov/paleo/treering. html and the data of the Gâvre Forest (lower Loire valley area) and of the farm of La Bintinais (close to Rennes in eastern Britanny) were produced by Guibal (Institut Mediterranean Institute of Ecology and Paleoecology, Marseille). The data recorded from 16 referential sites allowed to take the period 1880-1995 into account.

The average monthly temperature and the monthly precipitation amounts for the period 1880-1980 got out the GHCN file (CDIAC/ORNL and NCDC) and were collected using the French Bulletins du Centre Météorologique for the late XIXth century and the early XXth century, using the Résumés mensuels du temps of the French meteorological office (Météo-France) for the XXth century and got out the Météo-France database. Reference meteorological stations were selected close to the sites of tree samples, to identify the climatic features associated with the negative characteristic years. In order

\section{Tree-ring analysis and droughts in northwestern France \\ O. Planchon et al.}
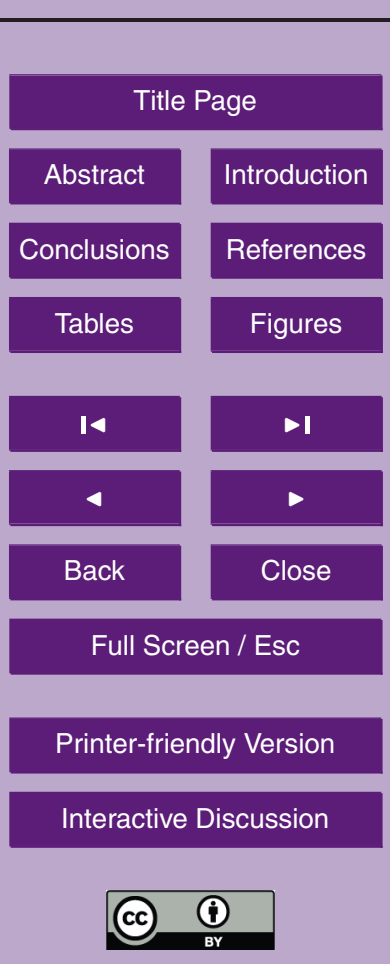
to show more precise results about the precipitation anomalies and their space-time distribution, monthly precipitation data were obtained from 20 meteorological stations of the Météo-France network over the studied area for the period 1881-1980 (Fig. 2b).

\section{Results and discussion}

\section{$5 \quad 3.1$ Identification and typology of drought periods}

The best data coverage (number of tree-rings per year) was obtained for the period 1880-1980, as shown on Fig. 3. Monthly climate data have been collected for that period. During the studied period, 19 negative characteristic years were identified and the climate data analysis and results of the investigations by Dubreuil (1994) showed 10 that all these years were subjected to drought events: $1885,1887,1891,1896,1898$, 1900, 1905, 1911, 1915, 1919, 1921, 1928, 1933, 1934, 1949, 1952, 1959, 1972 and 1976. Drought is a regionally persistent and slowly developing hydrological phenomenon leading to a significant threat to water resources (Stahl et al., 2002). An atmospheric drought signal (dry weather period) causes a regional precipitation deficit over an extend period of time, which eventually results in a hydrological drought. As drought affect the vegetation growth, tree rings may be precise indicators of past droughts, their intensity and spatial extent (Cook et al., 1999; Bonin and Burn, 2005). Drought can be defined by the combination of a precipitation deficit and high temperature anomalies (especially in the warm season). In this paper, drought periods (especially in the warm season) were at first identified using climate (ombrothermic) diagrams $P=2 T$ ( $P$ : precipitation expressed in $\mathrm{mm} ; T$ : temperature expressed in $\left.{ }^{\circ} \mathrm{C}\right)$, according to Bagnouls and Gaussen (1957) and Walter and Lieth (1964). Taking these diagrams into account, a month with $P<2 T$ is classified "dry". This method allowed to classify the negative characteristic years identified and mapped in northwestern France (maps of growth index) in four types of years affected by droughts. Figure 4 shows one reference map of growth index for each class of year. Figure 5 shows climate diagrams of

Tree-ring analysis and droughts in northwestern France

O. Planchon et al.
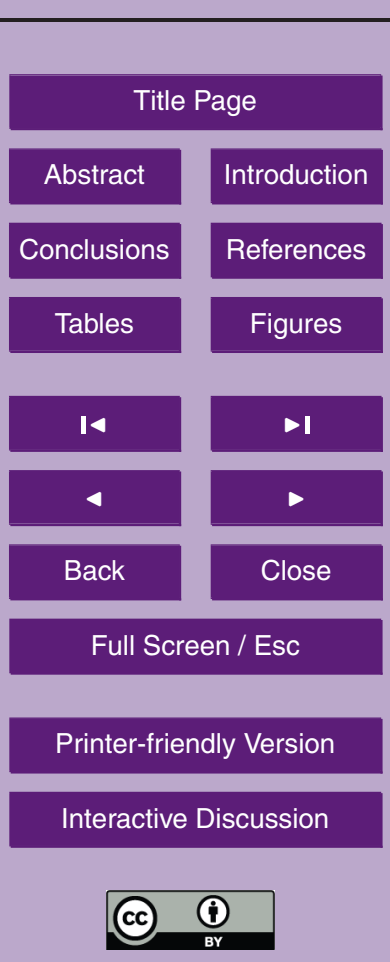
Paris (Montsouris Park) and Rennes for each of these selected years (location of these stations: see Fig. 1b). According to the characteristics of the drought in northwestern France, the negative characteristic years were classified as follow:

Type 1 (Fig. 4a). Continuous and intense drought during all the vegetative period 5 (spring and summer): 1896, 1921, 1949, 1976, and secondarily (shorter period of drought) 1900, 1911.

Type 2 (Fig. 4b). Summer drought succeeding no precipitation deficit in spring: 1898, 1928, 1933, 1952, 1959; (without shrivelling): 1885 and 1887; (discontinuous): 1919.

Type 3 (Fig. 4c). Remarkable winter drought: 1891, 1905, 1934.

$10 \quad$ Type 4 (Fig. 4d). Unclassified years without $P<2 T$ values: 1915, 1972.

Drought is the most discriminant climatic feature among the negative characteristic years. Several distinctive features of the drought were shown, depending on the duration, the intensity and the season(s) of drought. These features and the hydrological balance have an impact on the plant growth and should be take into account.

15 The intensity of the hydrological deficit depends on the drought characteristics abovementioned. The hierarchy of the negative characteristic years essentially depends on the duration and intensity of droughts in summer and/or spring, whereas autumn is not a discriminant season. The results of this classification were confirmed and precised using other methods, especially to identify winter droughts and to explain the particularity of the "type 4" years (1915 and 1972, without dry months according to the climate diagrams: for the year 1972, see Fig. 5). Precipitation differences were calculated using monthly data of 20 meteorological stations of the Météo-France network over the studied area (Fig. 1b), for the period of December-August 1880-1980 at monthly and seasonal timescales. The results confirmed the classification of the 19 negative characteristic years based on the duration and the intensity of the drought, and also based on the seasons most affected by the drought (Table 1).

During the first class of type 1 (a: years 1896, 1921, 1949, 1976), the above mentioned drought in spring and summer succeeded a strong precipitation deficit in winter. Therefore, during these years, the three consecutive seasons of winter, spring and

\section{Tree-ring analysis and droughts in northwestern France \\ O. Planchon et al.}
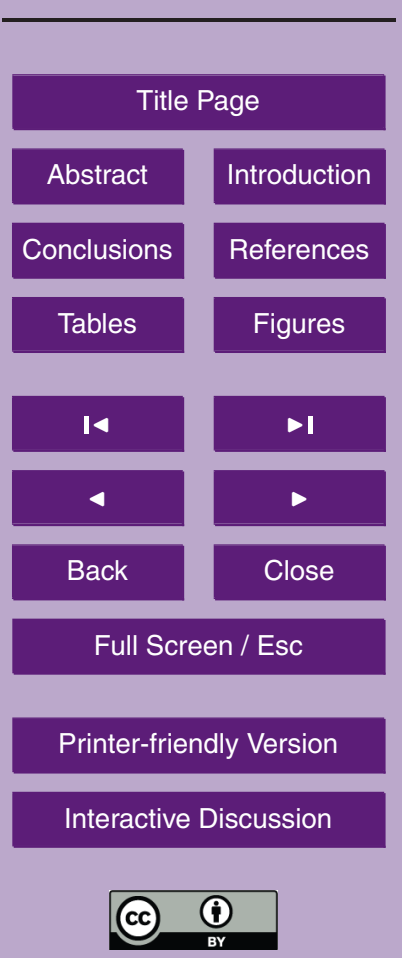
summer were subjected to great negative precipitation differences in most of the reference stations and involved the lowest growth index over most of the studied area. During the other years of the type $1(1900,1911)$, winter was not subjected to precipitation deficits (1900) and/or the period of precipitation deficit in spring-summer was 5 interrupted by some wet months e.g. in June 1911. The shorter periods of drought during the years of types 2 (b) and 3 (c) resulted in negative but smaller precipitation differences for all the period of December-August. The percent difference in precipitation for the years of type 3 clearly shows the strong deficit in winter, compared with the other seasons. In 1915 and 1972, precipitation deficits were recorded for several but not successive months, over an heterogeneous spatial distribution.

In spite of the wide impact of the droughts, their effects are not homogeneous at regional and local scales. The spatial distribution of the plant growth index associated with the Type 1 (Fig. 4a) showed that the growth drop was lessened in the forests located on the highest reliefs (hills of Normandy). The hydrological deficit was probably smaller on the hills of the Armorican massif (lower temperature and evapotranspiration) than in the neighbouring plains, especially in the plains and low plateaus of the central and southern Paris basin and the lower Loire valley area. The usually wettest sites were the least subjected to the droughts, according to Dubreuil (1996) and according to Fig. 1b. The spatial differences shown on the maps of the other types (Fig. 4b, c, d) were also due to the regulation process by the vegetation cover or the soil. Such a result points out particularities of the spatial distribution of the hydrological stress and should be confirmed and developed at a local-scale in topoclimatological studies.

\subsection{Hydrological balance and prevailing weather patterns}

The hydrological balance for the station of Rennes (Brittany) confirmed the above men25 tioned results, in accordance with the intensity and/or duration of drought periods. Water balance for all the stations of western France shows an obvious risk of drought occuring mostly in summer. Whereas average precipitation data do not clearly show this problem, the interannual variability of evaporation deficiency underlines the phe-

\section{Tree-ring analysis and droughts in northwestern France \\ O. Planchon et al.}
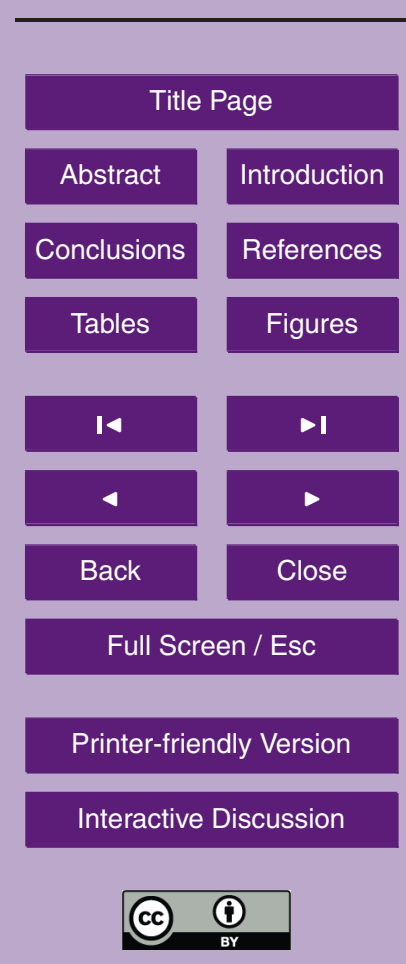
nomenon with a better accuracy. In this study, we used the difference between the potential evapotranspiration of Turc and the present evapotranspiration to quantify the deficit in spring (March, April and May) and in summer (June, July and August). In winter, the hydrological surplus was calculated for the months of December, January and

5 February. In order to compare with dendrochronological data, we used homogenized series of temperature and precipitation at Rennes (period 1880-1980) as described by Moisselin et al. (2002). For the implementation of the Turc formula we also used an estimation of the monthly sunshine duration:

Estimated sunshine duration $=26.88^{\star}(T x-T n)-963$

10 with $T \mathrm{n}$ : monthly mean of minimal temperature and $T x$ : monthly mean of maximal temperature.

(The coefficient of determination $R^{2}$ was 0.85 for the period 1961-1990)

Figure 6 shows the chronology of the spring and summer deficits between 1880 and 1980. The interannual average for the summer deficit was about $125 \mathrm{~mm}$ (ranging from $158 \mathrm{~mm}$ in 1882 to $272 \mathrm{~mm}$ in 1949) while the spring deficit was $21 \mathrm{~mm}$ and the average winter surplus was about $100 \mathrm{~mm}$ (the intense surplus of 1936 year of great flood in the city of Rennes). During the selected century, 13 years recorded a summer deficit of more than $200 \mathrm{~mm}$ and 8 years recorded a spring deficit of more than $50 \mathrm{~mm}$. The intense summer droughts of 1976 and 1949 were clearly shown. Some of the years pointed out in the dendrochronological study are also shown on this graph: 1921, 1959,1887 . Some of the winter deficits are present in the two approaches too: 1891, 1905 and 1934. Despite these results, some summers and springs well shown in the dendrochronological study did not correspond to strong hydrological deficits in summer $(1898,1919)$. Conversely, several years characterized by strong deficits were not well shown in the dendrochronological series in summer $(1892,1893,1906,1943)$, in spring $(1893,1938)$ or in winter $(1901,1909,1954)$. Therefore, the tree-ring analysis must be go deeper, in association with a detailed study of the climatic causes of the different drought patterns using long-time climate data series.

Drought events in summer or autumn often occured after winter periods with extreme

\section{Tree-ring analysis and droughts in northwestern France \\ O. Planchon et al.}
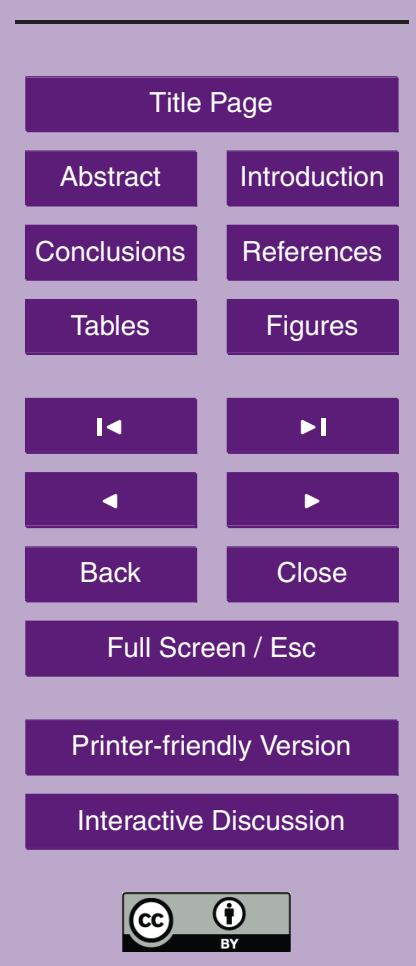
streamflow deficiencies. Zaidman et al. (2001) found that groudwater fed catchments in chalk geology regions of southeastern UK and northwestern France appear to be prone to this behaviour if groundwater recharge winter is lower than normal. However, not all winter deficiencies are followed by a summer drought, and not all summer 5 droughts are preceded by lower than usual winter streamflows (Stahl, 2001). Droughts in northwestern France are due to the persistence of high surface pressure areas over western and/or central Europe. Therefore, the prevailing weather disturbances tracks are deflected northwards and anticyclonic conditions were observed in $70 \%$ of the dry periods of ten days between 1951 and 1980 (Perron, 1990; Dubreuil, 1994). Variation 10 in intensity and in spatial extent of droughts may be due to the different large-scale weather patterns over Europe, which cause the drought conditions. These patterns were reported e.g. by Stahl (2001) for the period 1962-1990. Winter precipitation deficits were often associated either with blocking high pressure systems over Europe and reduced zonal circulation (e.g. 1890-1891) or zonal circulation of long periods

of anticyclonic conditions. Most of the severe summer droughts across Europe were associated with high pressure systems across central Europe (e.g. 1898). Long and multi-seasonal droughts (e.g. 1976) were associated with a complex succession of different weather patterns including varied and frequent anticyclonic conditions. Different types of anticyclonic conditions irregularly affected the year 1972 too. The analysis western and northwestern France will be useful to improve the climatic interpretation of the growth index maps. Such an analysis is possible and will be developed using the objective computational version of the Hess-Brezowsky Grosswetterlagen system (GWL) of classifying European synoptic regimes, from 1850 to the present (James, 2007).

\section{4, 249-270, 2008}

Tree-ring analysis and droughts in northwestern France

O. Planchon et al.
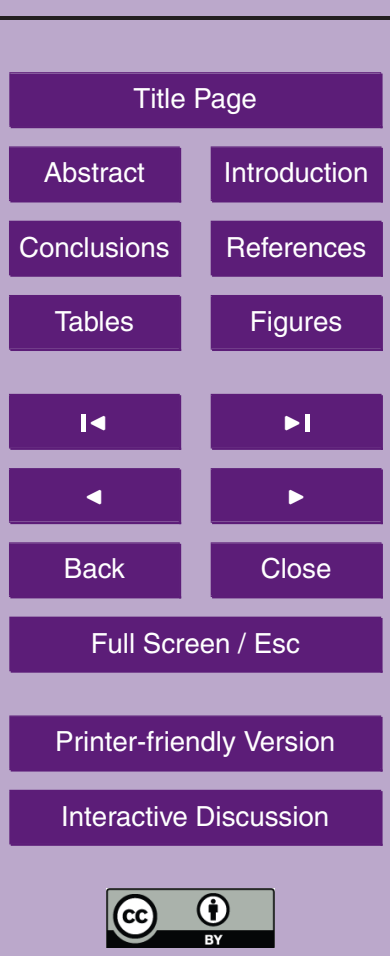


\section{Conclusions}

The results presented in this paper showed the effects of different types of droughts on the oak trees growth index in northwestern France, during the late XIXth and XXth century. Four types of droughts were identified using the results of the tree-ring analy5 sis and the available climate data. The long, intense and countinuous droughts clearly showed a spatial structuring effect on the growth index, especially when the two successive vegetative seasons (spring and summer) recorded strong precipitation deficits combined with shrivellings. These extreme cases involved the lowest growth index over most of the studied area, with some variations due to the altitude and exposure effects on the local-scale spatial distribution of the hydrological stress. A climatic interpretation could so be possible especially in these cases of relatively homogeneous low growth index over most of northwestern France and with an application to the medieval times. In order to improve the climatic interpretation of the growth index maps of the medieval times and perhaps on other periods, the cause of the different drought patterns will be more precisely studied during the contemporary period (late XIXth century and all the XXth century): i) with the analysis of the frequency of the large-scale circulation patterns for the characteristic years using the GWL catalogue, ii) with the analysis of the linkage between the circulation patterns and the space-time variability of the precipitation anomalies during the characteristic years.

Despite these results, some summers and springs well shown in the dendrochronological study did not correspond to strong hydrological deficits in summer. Conversely, several years characterized by strong deficits were not well shown in the dendrochronological series in summer, in spring or in winter. Therefore, the tree-ring analysis must be go deeper. Parallel to the tree-ring analysis, the mapping of the precipitation anomalies

and on the seasons affected by the precipitation deficit.

\section{Tree-ring analysis and droughts in northwestern France \\ O. Planchon et al.}

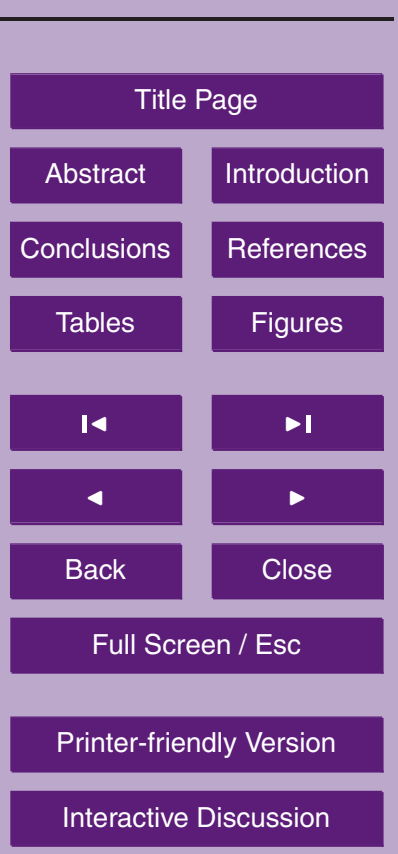




\section{References}

Bagnouls, F. and Gaussen, H.: Saison sèche et indice xérothermique, Bull. Soc. Hist. Nat., Toulouse, 88, 193-239, 1957.

Blain, S., Planchon, O., and Bernard, V.: Cartographie des données dendrochronologiques du nord-ouest de la France pour la période médiévale $\left(\mathrm{XIV}^{e}-\mathrm{XV}^{e}\right.$ siècles) : essai d'interprétation climatique, Actes du $19^{e}$ colloque de l'AIC, Epernay, 3, 131-135, 2006.

Bonin, D. and Burn, D.: Use of tree ring reconstructed streamflows to assess drought, Canadian Journal of Civil Engineering, 32(6), 1114-1123, 2005.

Cook, E. R., Meko, D. M., Stahle, D. W., and Cleaveland, M. K.: Drought reconstructions for the continental United states, J. Climate, 12, 1145-1162, 1999.

Dubreuil, V.: La sécheresse dans la France de l'Ouest : étude d'après les bilans hydriques et les données des satellites NOAA-AVHRR. Doctoral Thesis, Rennes-2 University (F), 381 p, 1994.

Dubreuil, V.: Synthèse géographique de la sécheresse dans les régions océaniques, La Météorologie ( $8^{e}$ série), 15, 22-34, 1996.

Dubreuil, V.: La sécheresse dans la France de l'Ouest: une contrainte climatique trop souvent oubliée, Sécheresse, 8(1), 47-55, 1997.

Dubreuil, V., Mounier, J., and Lejeune, C.: L'accentuation récente du déficit estival dans la France océanique, Publications de l'Association Internationale de Climatologie, 11, 151157, 1998.

Emberger, L.: Une classification biogéographique des climats, Recueil des travaux des laboratoires de la Faculté des Sciences de Montpellier, 7, 3-43, 1955.

Jones, P. D. and Mann, M. E.: Climate over past millennia, Reviews of Geophysics, 42, RG2002, 42 pp., 2004.

James, P. M.: An objective classification for Hess and Brezowsky Grosswetterlagen over Europe, Theoretical and Applied Climatology, 88, 17-42, 2007.

Jones, P.D., Osborn, T.J. and Briffa, K.R.: The evolution of climate over the last millenium, Paleoclimate review, 292, 662-667, 2001.

Kessler, J. and Chambraud, A.: La Météo de la France, in: tous les climats localité par localité, edited by: J. C. Lattès, 312 p., 1986.

Kiely, G.: Climate change in Ireland from precipitation and streamflow observations, Advances in Water Resources, 23, 141-151, 1999.
4, 249-270, 2008

Tree-ring analysis and droughts in northwestern France

O. Planchon et al.

\section{Title Page}

Abstract

Introduction

Conclusions

References

Tables

Figures

14

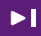

$<$

Back

Close

\section{Full Screen / Esc}

Printer-friendly Version

Interactive Discussion

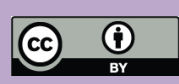


Kilsby, C. G., editor: Water Resources: Influence of Climate change in Europe ENV4-CT970452, Water Resource Systems Research Laboratory, University of Newcastle, NewcastleUpon-Tyne (UK), 96 p., 2001.

Lambert, G.N.: La dendrochronologie, mémoire de l'arbre, in: A. Ferdière, Les méthodes de datation en laboratoire, Errance, Paris (F), 13-69, 1998.

Lloyd-Hughes, B.: The long-range predictability of European drought, Doctoral Thesis, University of London (UK), 203 p., 2002.

Masson-Delmotte, V., Raffalli-Delerce, G., Danis, P. A., Yiou, P., Stievenard, M., Guibal, F., Mestre, O., Bernard, V., Goosse, H., Hoffmann, G., and Jouzel, J.: Changes in European precipitation seasonality and in drought frequencies revealed by a four-century-long tree-ring isotopic record from Brittany, western France, Clim. Dynam., 24, 57-69, 2005.

MÉTÉO-FRANCE: Normales climatiques Période 1961-1990, Toulouse (F): Service Central d'Exploitation de la Météorologie, Tome 1 - Stations de métropole.

Moisselin, J. M., Schneider, M., Canellas, C., and Mestre. O.: Changements Climatiques en 15 France au 20ème siècle : étude des longues séries de données homogénéisées françaises de précipitations et températures, La Météorologie, 38, 45-56, 2002.

Perron, G.: Types de temps et ensoleillement en climat océanique: une méthode de climatologie appliquée à la Bretagne, Doctoral Thesis, Rennes-2 University (F), 312 p., 1990.

Stahl, K.: Hydrological drought: A study across Europe, Doctoral thesis, Albert-LudwigsUniversität Freiburg i. Br. (D), 122 p., 2001.

Turc, L.: Evaluation des besoins en eau d'irrigation, évapotranspiration potentielle, Annales Agronomiques, 1, 13-49, 1961.

Walter, H. and Lieth. H.: Klimadiagramm-Weltatlas, Verlag Gustav Fischer, Jena (D), 8000 stations and 55 maps, 1964.

Zaidman, M. D., Rees, H. G., and Young, A. R.: Spatio-temporal development of streamflow droughts in north-west Europe, Hydrology and Earth System Sciences, 5(4), 733-751, 2001.

\section{Tree-ring analysis and droughts in northwestern France}

O. Planchon et al.

\section{Title Page}

Abstract

Introduction

Conclusions

References

Tables

Figures
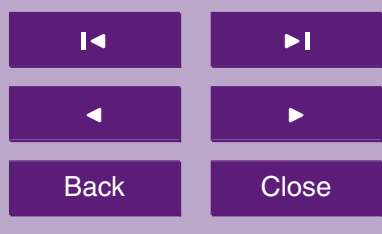

Back

Close

Full Screen / Esc

Printer-friendly Version

Interactive Discussion

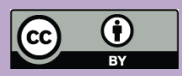


Table 1. Percent difference in precipitation at the meteorological stations of Paris (Montsouris park) and Rennes, for the negative characteristic years (period December-August: winter/DJF, spring/MAM and summer/JJA) relative to 1881-1980 average. Winter includes the month of December of the previous year. (a) Type 1: long and intense drought, (b) Type 2: summer drought, (c) Type 3: winter drought, (d) Type 4: years with discontinuous short periods of negative precipitation differences.

\begin{tabular}{lllllllll}
\hline \multicolumn{7}{c}{ Station of PARIS (Montsouris park) } & \multicolumn{7}{c}{ Station of RENNES } \\
\hline Years & Winter & Spring & Summer & Year & Winter & Spring & Summer & Year \\
\hline (a) 1896 & -61.0 & -78.0 & +7.8 & -41.6 & -35.1 & -43.7 & -14.5 & -31.3 \\
1900 & +47.8 & -44.5 & -38.5 & -12.9 & +36.7 & -28.4 & -10.7 & +2.1 \\
1911 & -41.7 & -24.9 & -47.4 & -38.4 & -40.8 & -24.4 & +20.9 & -16.6 \\
1921 & -56.4 & -48.7 & -55.6 & -53.7 & -59.0 & -16.1 & -44.3 & -41.3 \\
1949 & -43.8 & -44.7 & -59.6 & -49.8 & -44.1 & -29.2 & -59.9 & -44.5 \\
1976 & -65.3 & -52.3 & -33.9 & -49.8 & -51.8 & -62.6 & -37.1 & -50.5 \\
(b) 1885 & -15.3 & -15.3 & -7.6 & -12.5 & +0.1 & -0.2 & -31.8 & -9.9 \\
1887 & -35.1 & -11.2 & -3.0 & -15.9 & +0.7 & -35.7 & -41.0 & -23.4 \\
1898 & -15.0 & +27.0 & -28.4 & -6.4 & -31.6 & -3.4 & -12.5 & -17.0 \\
1919 & +58.9 & +14.2 & -28.9 & +12.8 & +67.3 & +45.4 & -19.2 & +33.7 \\
1928 & +13.1 & +53.1 & -21.4 & +13.4 & +25.5 & +56.9 & -38.4 & +15.2 \\
1933 & -45.8 & -3.3 & -41.5 & -30.7 & -17.3 & -0.2 & -39.3 & -18.9 \\
1952 & +3.7 & +1.8 & -37.2 & -11.7 & -3.3 & -7.0 & -22.4 & -10.4 \\
1959 & +9.7 & -3.0 & -68.7 & -22.7 & +5.7 & +35.2 & -46.8 & -1.6 \\
(c) 1891 & -67.2 & +26.4 & -6.1 & -15.2 & -63.0 & +7.1 & +8.7 & -19.3 \\
1905 & -1.2 & +39.2 & +43.2 & +27.8 & -23.2 & +34.5 & +31.3 & +11.4 \\
1934 & -53.7 & -31.6 & -12.5 & -31.7 & -44.1 & +6.5 & -28.2 & -23.7 \\
(d) 1915 & +37.9 & -17.3 & +5.8 & +8.6 & +83.3 & -51.9 & +53.7 & +32.8 \\
1972 & +13.9 & +3.1 & +62.1 & +27.9 & +20.8 & -0.6 & -14.7 & +3.2 \\
\hline
\end{tabular}

4, 249-270, 2008

\section{Tree-ring analysis and droughts in} northwestern France

O. Planchon et al.

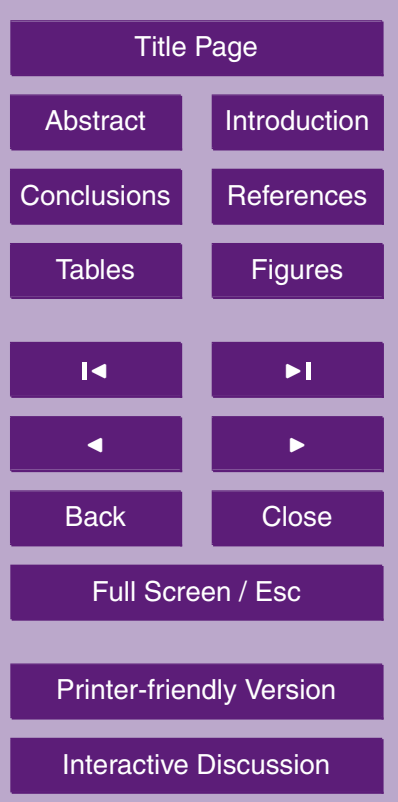



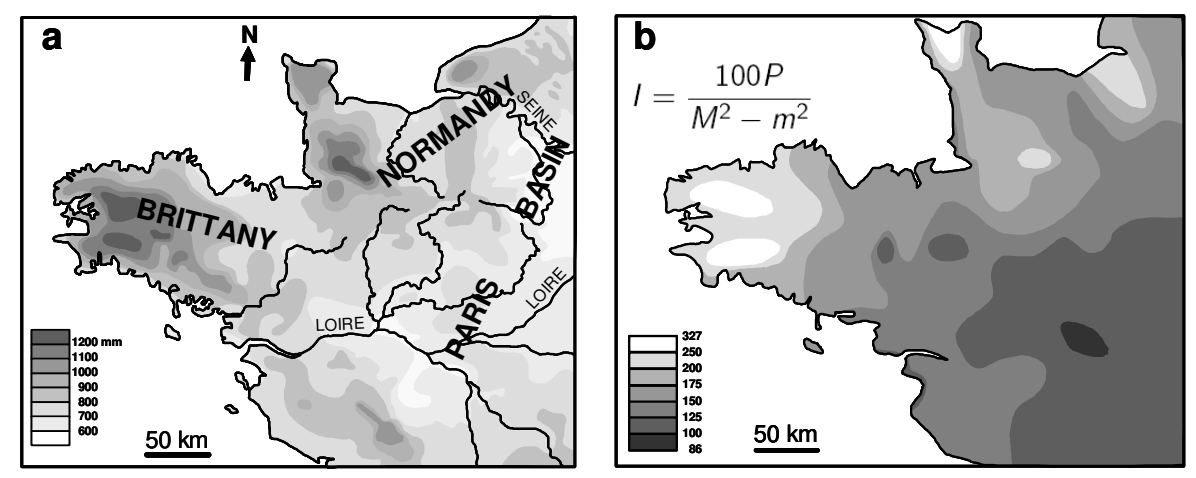

\section{Tree-ring analysis and droughts in northwestern France \\ O. Planchon et al.}

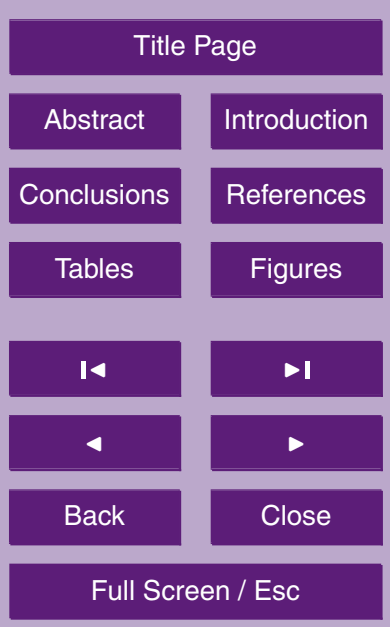

Fig. 1. (a) Average annual precipitation in north-western France for the climatological period 1961-1990, according to Kessler and Chambraud (1986) and MÉTÉO-FRANCE: Climate Normals 1961-1990, (b) Distribution of the Emberger index in northwestern France for the climatological period 1961-1990, according to Dubreuil (1994): $P=$ Annual precipitation (mm), $M=$ Average daily maximum temperature of the warmest month, $m=$ Average daily minimum temperature of the coldest month.

Printer-friendly Version

Interactive Discussion 


\section{a}

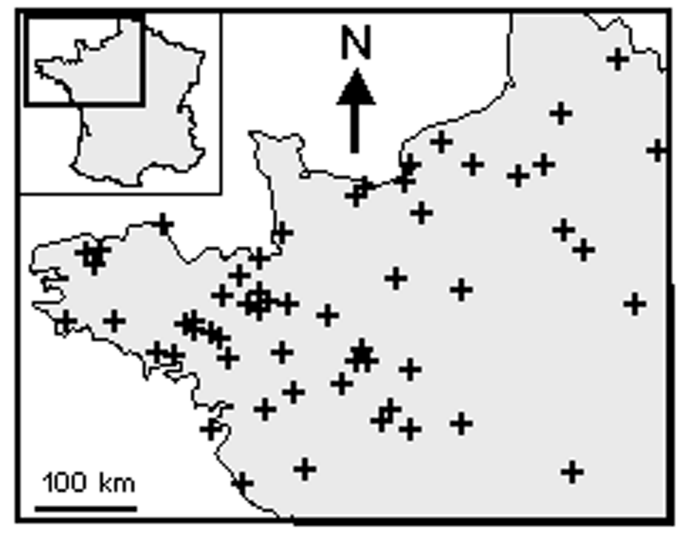

b

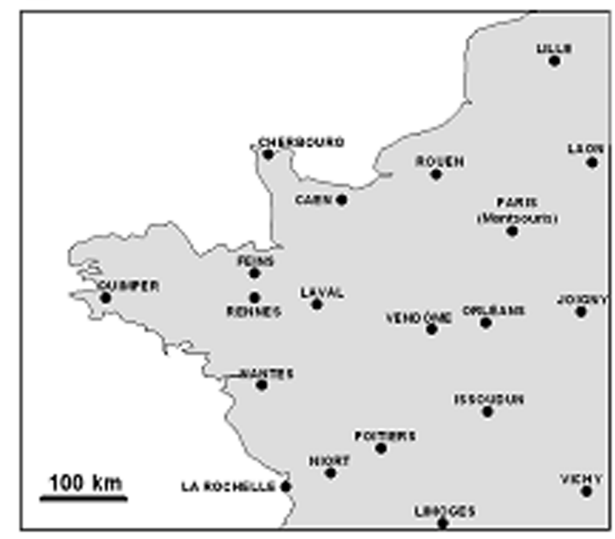

Fig. 2. Location of the studied dendrochronological sites (a) and the main reference meteorological stations (b).

\section{Tree-ring analysis and droughts in northwestern France}

O. Planchon et al.

\begin{tabular}{|c|c|}
\hline \multicolumn{2}{|c|}{ Title Page } \\
\hline Abstract & Introduction \\
\hline Conclusions & References \\
\hline Tables & Figures \\
\hline I4 & $\bullet$ \\
\hline 4 & $\bullet$ \\
\hline Back & Close \\
\hline Full Screen / Esc \\
\hline
\end{tabular}

Printer-friendly Version

Interactive Discussion

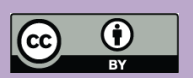




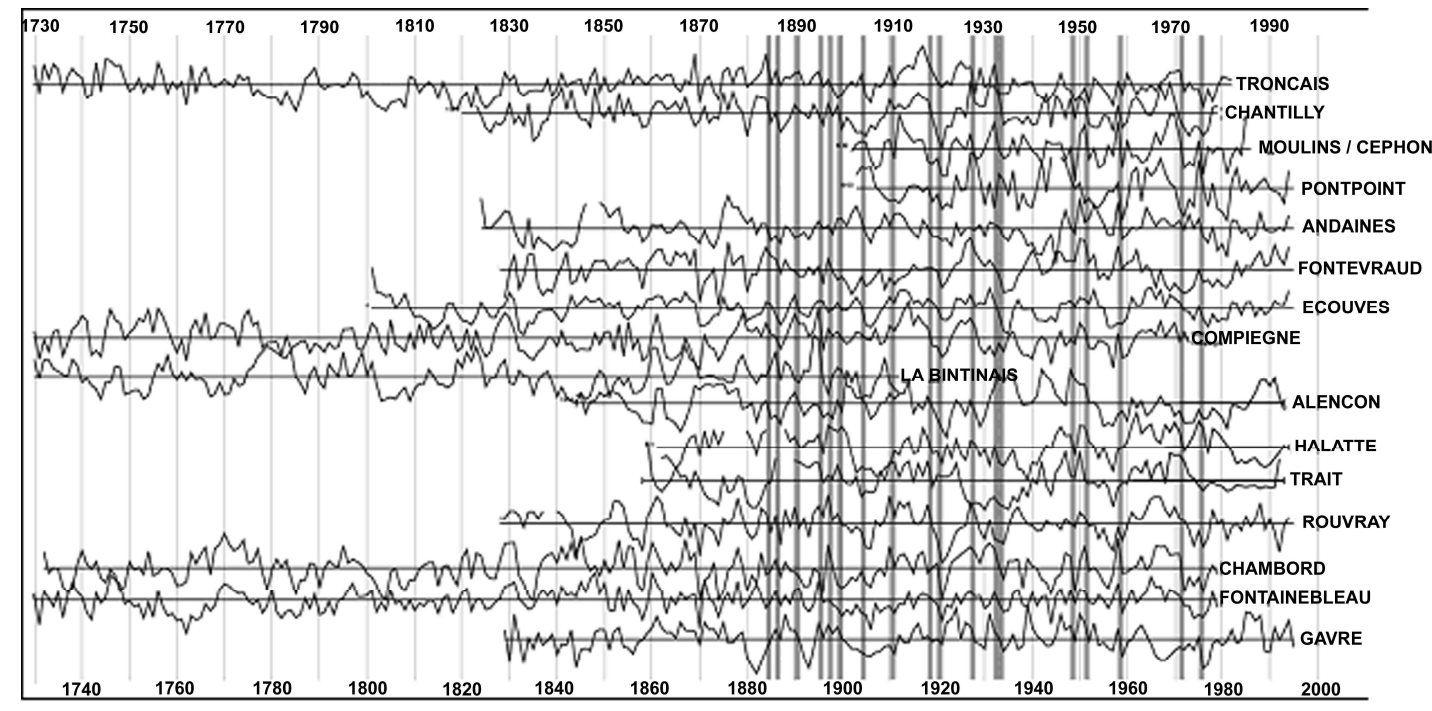

Fig. 3. Synchronization of the referential data series for the contemporary period. Grey vertical lines show the synchronous growth anomalies (negative characteristic years) for most of these referential data series.

\section{Tree-ring analysis and droughts in northwestern France \\ O. Planchon et al.}

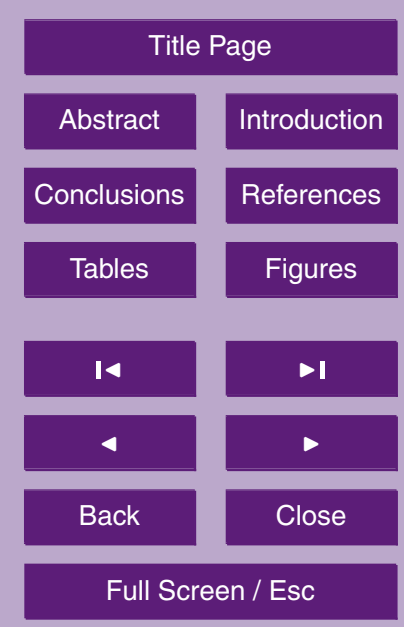

Printer-friendly Version

Interactive Discussion

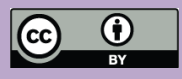




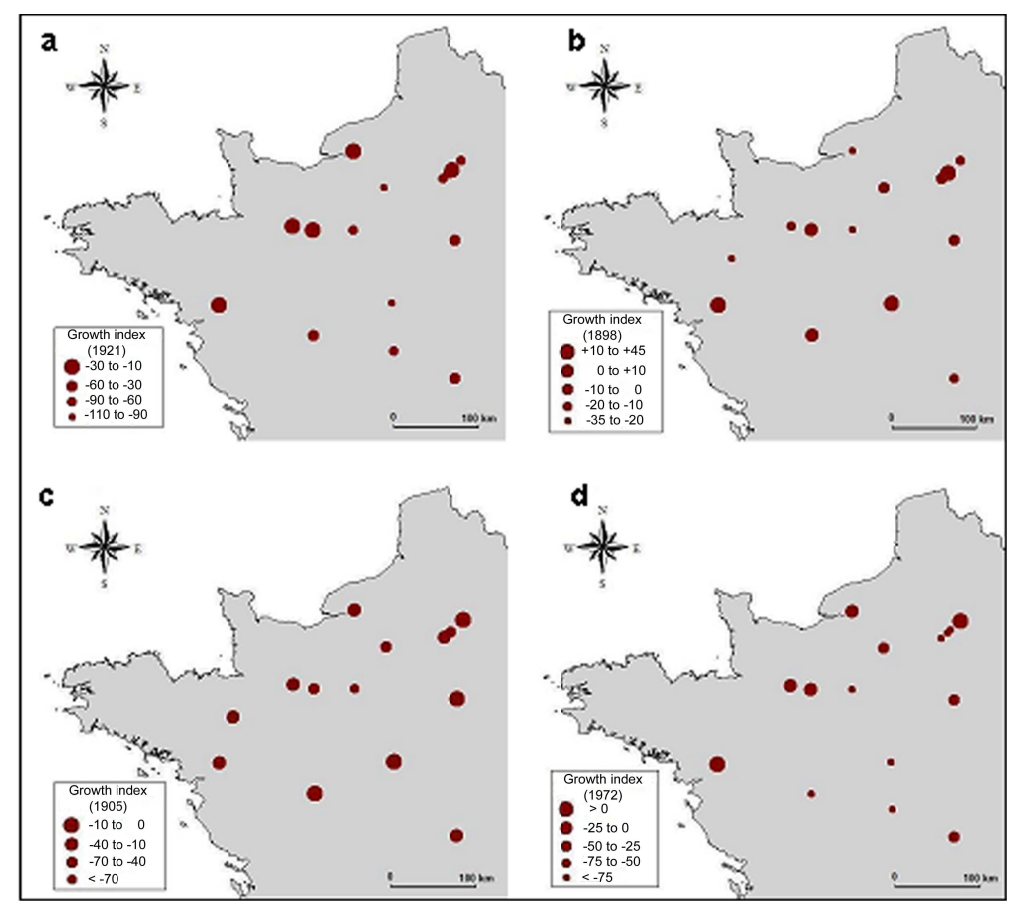

\section{Tree-ring analysis and droughts in northwestern France}

O. Planchon et al.

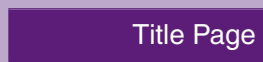

\begin{tabular}{|c|c|}
\hline Abstract & Introduction \\
\hline Conclusions & References \\
\hline Tables & Figures \\
\hline I & $\checkmark$ \\
\hline 4 & $\bullet$ \\
\hline Back & Close \\
\hline Full Screen / Esc \\
\hline
\end{tabular}

Fig. 4. Spatial distribution of the growth index for the years 1921 (a), 1898 (b), 1905 (c) and 1972 (d).
Printer-friendly Version

Interactive Discussion 
PARIS (Montsouris)
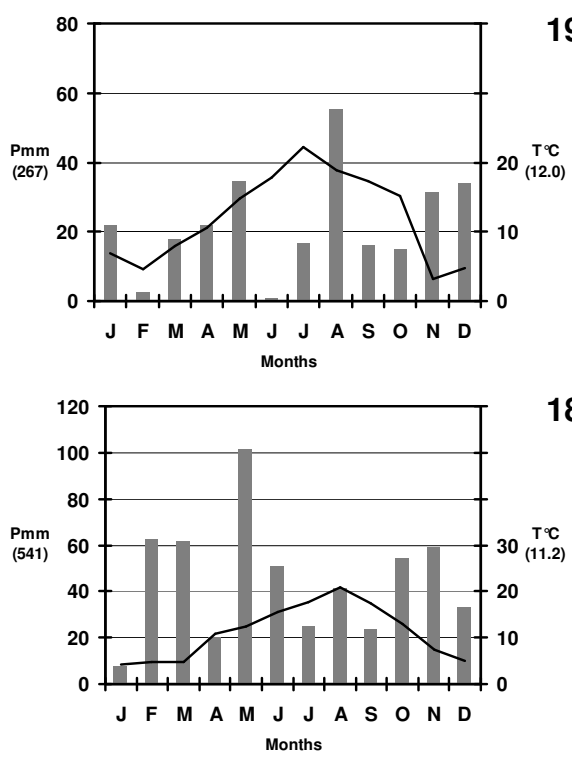

RENNES

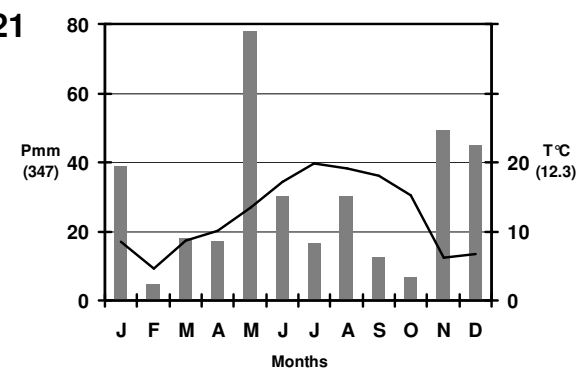

1898

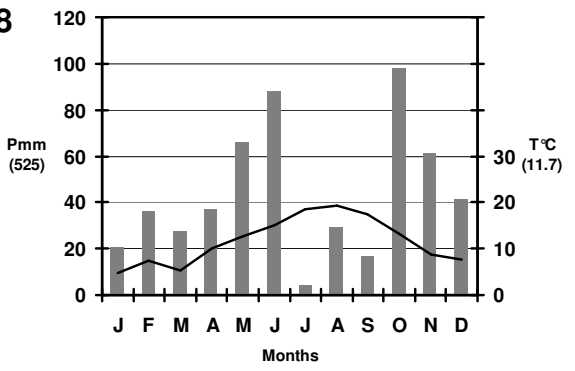

Fig. 5. Climate diagrams of 4 representative years among the identified negative characteristic years, for the stations of Paris (Montsouris park) and Rennes. Location of these stations: see Fig. 1b.

\section{Tree-ring analysis and droughts in northwestern France \\ O. Planchon et al.}

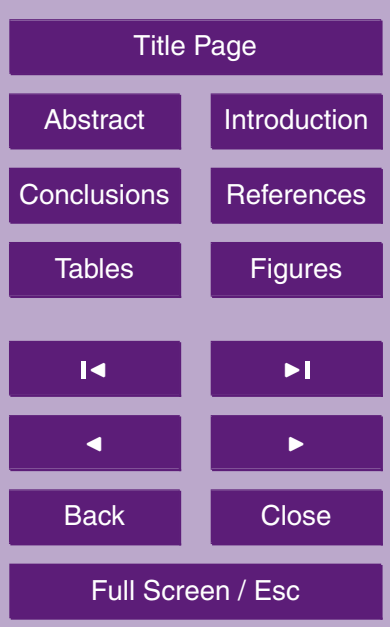

Printer-friendly Version

Interactive Discussion

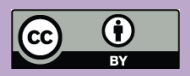



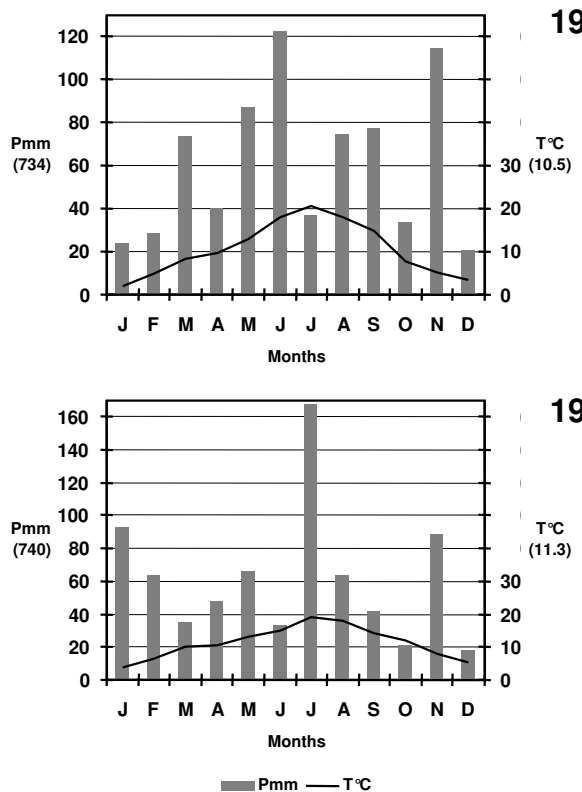

$=\mathrm{Pmm}-\mathrm{T}^{\circ} \mathrm{C}$
1905

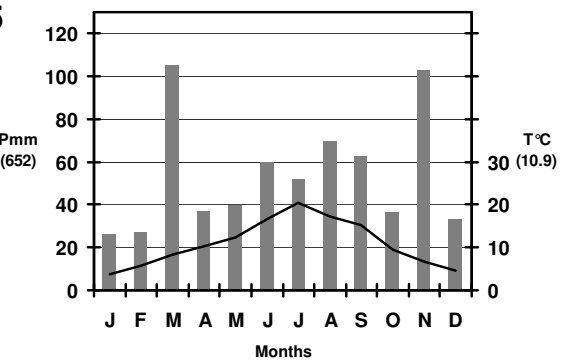

1972

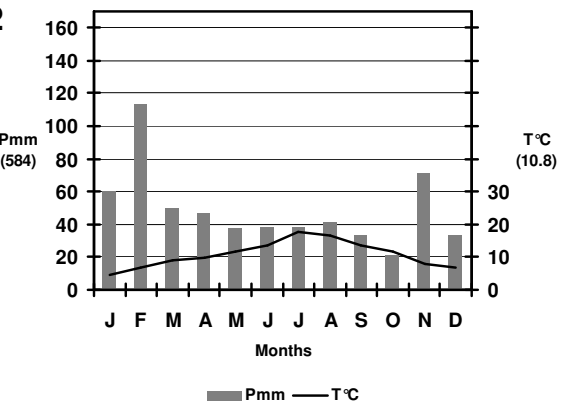

Fig. 5. Continued.

\section{Tree-ring analysis} and droughts in northwestern France

O. Planchon et al.

\section{Title Page}

Abstract

Introduction

Conclusions

References

Tables

Figures

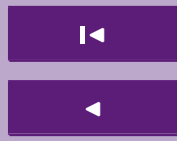

Back

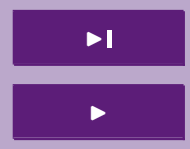

Close

\section{Full Screen / Esc}

Printer-friendly Version

Interactive Discussion

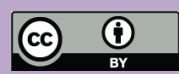




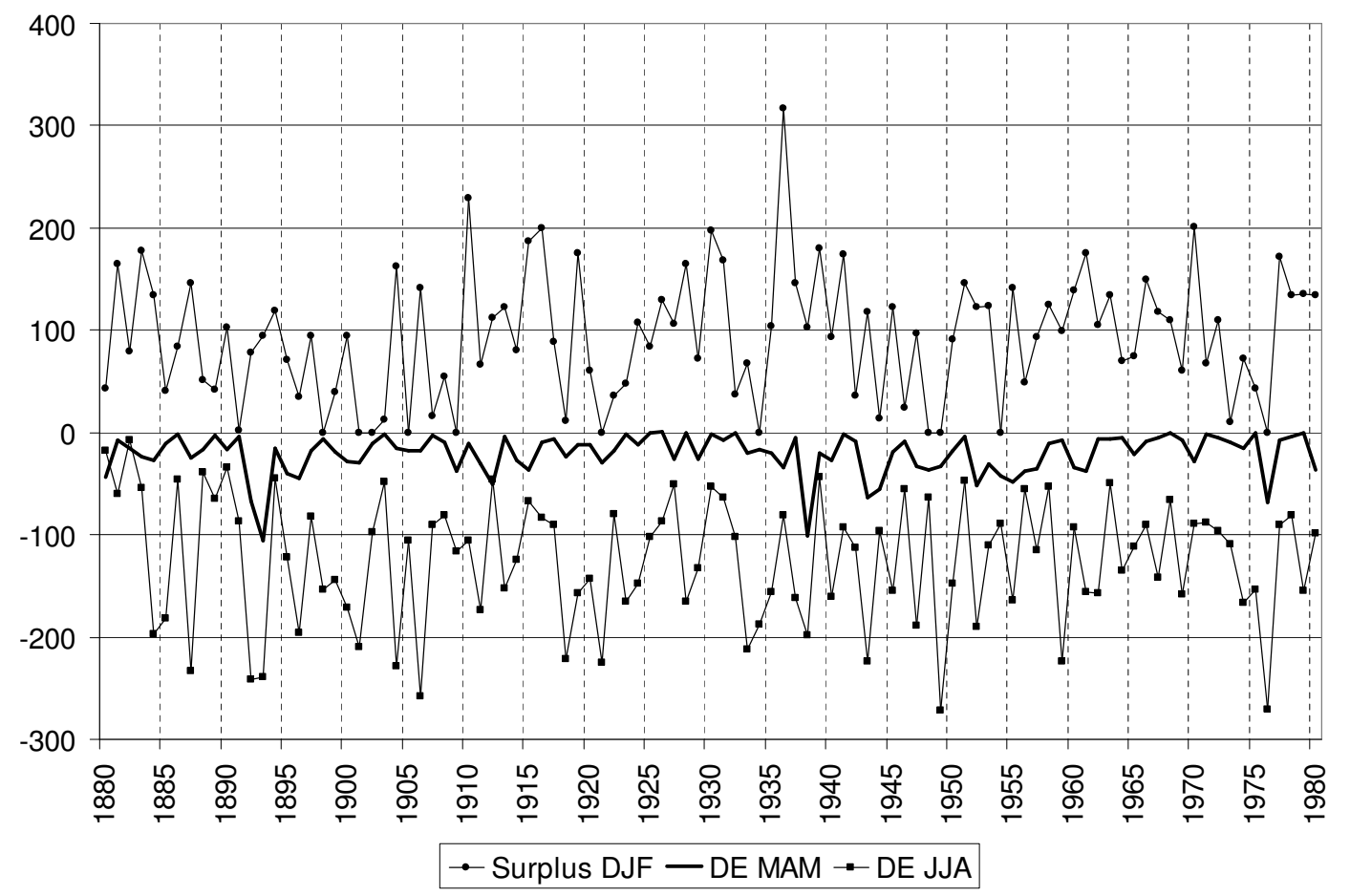

Fig. 6. Chronology of the spring (MAM) and summer (JJA) deficits and of the winter (DJF) surplus between 1880 and 1980 .

\section{Tree-ring analysis and droughts in northwestern France \\ O. Planchon et al.}

\section{Title Page}

Abstract

Introduction

Conclusions

References

Tables

Figures
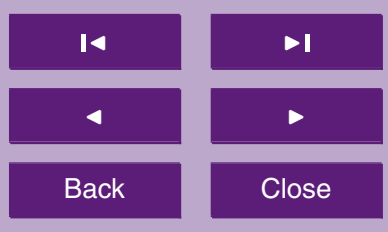

Full Screen / Esc

Printer-friendly Version

Interactive Discussion

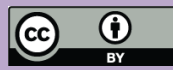

